\title{
Behaviors of Cellulose-Based Activated Carbon Fiber for Acetaldehyde Adsorption at Low Concentration
}

\author{
Dong-Yeon Ryu ${ }^{1}$, Koji Nakabayashi ${ }^{1,2}{ }^{\text {, Takaaki Shimohara }}{ }^{2}$, Ueda Morio ${ }^{3}$, Isao Mochida ${ }^{3}$, \\ Jin Miyawaki ${ }^{1,2}$, Yukwon Jeon ${ }^{4}$, Joo-Il Park ${ }^{5, *}$ and Seong-Ho Yoon 1,2,*(D) \\ 1 Interdisciplinary Graduate School of Engineering Science, Kyushu University, Kasuga, Fukuoka 816-8580, \\ Japan; dongyeon.ryu@nipponpapergroup.com (D.-Y.R.); nakabayashi@cm.kyushu-u.ac.jp (K.N.); \\ miyawaki@cm.kyushu-u.ac.jp (J.M.) \\ 2 Institute of Materials Chemistry and Engineering, Kyushu University, Kasuga, Fukuoka 816-8580, Japan; \\ shimohara@cm.kushu-u.ac.jp \\ 3 Kyushu Environmental Evaluation Association, Fukuoka 813-0004, Japan; ueda@keea.or.jp (U.M.); \\ mochida@keea.or.jp (I.M.) \\ 4 Department of Environmental Engineering, Yonsei University, Wonju 26493, Korea; ykjeon@yonsei.ac.kr \\ 5 Department of Chemical and Biological Engineering, Hanbat National University, Daejeon 34158, Korea \\ * Correspondence: jipark94@hanbat.ac.kr (J.-I.P.); yoon@cm.kyushu-u.ac.kr (S.-H.Y.); \\ Tel.: +82-42-821-1530 (J.-I.P.); +81-92-583-7959 (S.-H.Y.)
}

Received: 25 November 2019; Accepted: 16 December 2019; Published: 18 December 2019

\begin{abstract}
The toxic nature of acetaldehyde renders its removal from a wide range of materials highly desirable. Removal of low-concentration acetaldehyde (a group 1 carcinogenic volatile organic compound) using an adsorbent of cellulose-based activated carbon fiber modified by amine functional group (A@CACF-H) is proposed, using 2 ppm of acetaldehyde balanced with $\mathrm{N}_{2} / \mathrm{O}_{2}(79 / 21 \% \mathrm{v} / \mathrm{v})$ observed under continuous flow, with a total flow rate of $100 \mathrm{~mL} / \mathrm{min}$ over $50 \mathrm{mg}$ of A@CACF-H. The effective removal of the targeted acetaldehyde is achieved by introducing the functionalized amine at optimized content. The removal mechanism of A@CACF-H is elucidated using two-dimensional gas chromatography coupled with time-of-flight mass spectrometry (2D-GC TOF-MS), indicating the efficacy of the proposed acetaldehyde removal method.
\end{abstract}

Keywords: activated carbon fiber; removal; adsorption; acetaldehyde; aniline; amine

\section{Introduction}

A great deal of attention has been paid to gaseous carbonyl chemicals with aldehyde species (acetaldehyde, $\mathrm{CH}_{3} \mathrm{CHO}$ ) due to associated adverse health effects. $\mathrm{CH}_{3} \mathrm{CHO}$ is known as one of several "sick house gases", found in furniture, decorating materials, and cigarettes, and is associated with the cooking and burning of fossil fuels at atmospheric conditions $\left(20^{\circ} \mathrm{C}, 1 \mathrm{~atm}\right)$ [1-3]. Moreover, $\mathrm{CH}_{3} \mathrm{CHO}$ is listed as a group 1 carcinogenic and a mutagenic priority pollutant [4-9]. In addition, low level exposure of acetaldehyde can cause respiratory issues, such as throat irritation, shortness of breath, eye irritation, and chest tightness [10]. Therefore, indoor $\mathrm{CH}_{3} \mathrm{CHO}$ content should be regulated and maintained below 0.03 ppm [9,11].

Condensation [12], recuperative and regenerative thermal oxidation [13], biofiltration [14,15], and catalytic oxidation and adsorption [16] are commonly applied techniques for eliminating volatile organic compounds (VOCs) such as $\mathrm{CH}_{3} \mathrm{CHO}$ from the gas stream. Among these standard methods, adsorption delivers the best results in terms of efficiency, energy costs, and versatility to different kinds of VOCs [17]. Finding the optimal porous solid adsorbent is crucial for the commercial application of adsorption technique. Carbon materials, in the spite of some inherent disadvantages such as hygroscopicity and pore blocking, are recognized to have the most potential as a low-cost, 
high-efficiency adsorbent with good stability for VOC abatement [18]. In particular, activated carbon fiber (ACF) provides key advantages in terms of the adsorption process, due to a high specific surface area, low pressure drops, and suppressed mass transfer limitations $[19,20]$. Numerous results have been studied on ACFs in terms of the adsorption strength of ACFs with pore characteristics [21,22] and the adsorption capacity of VOCs onto ACFs depending on the polarity of VOC molecules [22-26]. Nevertheless, knowledge of the detailed molecular behavior of acetaldehyde adsorption over the ACFs or functionalized ACFs is still important. A recent report by Dumitrică allows us to consider the adsorption behavior of acetaldehyde over cellulose-based activated carbon fiber (CACF) and the removal mechanisms of acetaldehyde by the amine-functionalized CACF with suitable atomistic simulations from a molecular-level point of view [27].

The main aim of this study is to confirm the detailed adsorption behavior of low concentrations of acetaldehydes at the molecular level over amine-functionalized CACF-H (A@CACF-H). Therefore, this study is focused on investigating the adsorption behavior of low concentrations of acetaldehyde over cellulose-based ACF (CACF), heat-treated CACF (CACF-H), and A@CACF-H. Moreover, the detail reaction mechanism of acetaldehyde removal was also newly investigated with molecular level over A@CACF-H, using two-dimensional gas chromatography (2D-GC) coupled with TOF-MS.

\section{Materials and Methods}

\subsection{Materials}

The CACF obtained from East China University was synthesized as follows. The cellulose polymer fabricated as a felt type was stabilized and carbonized at $600^{\circ} \mathrm{C}$ by the spraying of potassium phosphate under a nitrogen atmosphere. It was then activated by steam at $800{ }^{\circ} \mathrm{C}$ to give the microporous characteristics of the final product. As a preliminary investigation of the calcination effect, the $\mathrm{CACF}$ was heat-treated (CACF-H) from $300-1400{ }^{\circ} \mathrm{C}$ at a heating rate of $10{ }^{\circ} \mathrm{C} \mathrm{min}^{-1}$ for $1 \mathrm{~h}$ under $\mathrm{N}_{2}$ at a flow rate of $100 \mathrm{~mL} \mathrm{~min}^{-1}$ in an infrared image furnace. After calcination, the CACF-H was soaked in the aniline-ethanol solution for the functionalization of the amine on the CACF-H (A@CACF-H). This procedure was conducted for $24 \mathrm{~h}$ without stirring, at $30^{\circ} \mathrm{C}, 1 \mathrm{~atm}$. The volume concentration of the aniline-ethanol solutions varied from 1-10\% v/v. Each sample was filtered and dried at $75{ }^{\circ} \mathrm{C}$ under vacuum conditions $(0.1 \mathrm{MPa})$ for $24 \mathrm{~h}$. For a precise comparison, phenol-resin-derived activated carbon (AC (MSP-20), Kansai Coke \& Chemicals Co., Japan), activated charcoal (K-C), and non-porous quartz wool $(\mathrm{QW})$ with an aniline soaking procedure were performed under the same conditions. The specific surface areas of pristine MSP-20, K-C, and QW were ca. 2000, 1900, and $0 \mathrm{~m}^{2} \mathrm{~g}^{-1}$, respectively. The elemental analyses were carried out using a carbon, hydrogen, and nitrogen ( $\mathrm{CHN}$ ) analyzer (MT-5, Yanako, Japan). The amount of oxygen content $\left(\mathrm{O}_{\text {diff. }}\right)$ was calculated by the subtraction of carbon, hydrogen, and nitrogen from $100 \%$ content. $\mathrm{N}_{2}$ adsorption/desorption isotherms at $77 \mathrm{~K}$ were measured using a volumetric adsorption system (Belsorp-Max-S, BEL Japan Inc., Japan). The specific surface areas were obtained using $\alpha_{\mathrm{s}}$ plots, and pore size distributions were obtained by non-localized density functional theory (NLDFT).

\subsection{Experimental Apparatus}

The experimental apparatus employed in acetaldehyde removal is represented in Figure 1. The acetaldehyde was generated using the permeation tube (P-92-1, GASTEC Co., Japan) at $35^{\circ} \mathrm{C}$ in a permeator (PD-1B, GASTEC Co.), with $\mathrm{N}_{2}$ flow set to $0.1 \mathrm{MPa}$ and $200 \mathrm{~mL} / \mathrm{min}$. The generated acetaldehyde was then divided using 2 ppm of gaseous acetaldehyde balanced with pure $\mathrm{N}_{2}$ standard gas was mixed with $79 \% \mathrm{v} / \mathrm{v}$ of $\mathrm{N}_{2}$ and $21 \% \mathrm{v} / \mathrm{v}$ of $\mathrm{O}_{2}$ at a total flow rate of $100 \mathrm{~mL} \mathrm{~min}^{-1}$. A fixed atmosphere of $40 \%$ humidity was carefully controlled by $\mathrm{N}_{2}$ bubbling. Each of the gases was controlled by the mass flow controller, and the mixed gas flowed into a packed glass tube with a diameter of $5.6 \mathrm{~mm}$ and a length of $50 \mathrm{~mm}$. The adsorbents were fixed at $50 \mathrm{mg}$ in a packing length of $\geq 25 \mathrm{~mm}$. The exhausted gases were analyzed by pumping using the detecting tube (92L, GASTEC Co.) with a 
sampling pump (GV-100, GASTEC Co.) at $100 \mathrm{~mL} \mathrm{~min}^{-1}$ [28]. The existence of acetaldehyde in the exhausted gases was confirmed by a color change in the detecting tube. The acetaldehyde reacted with hydroxylamine phosphate, which liberated phosphorus acid and aldoxime compounds. Liberated phosphoric acid reacts with a base to form phosphate and discolors reddish brown. The chemical stoichiometry is

$$
\begin{gathered}
3 \mathrm{CH}_{3} \mathrm{CHO}+\left(\mathrm{NH}_{2} \mathrm{OH}\right)_{3} \mathrm{H}_{3} \mathrm{PO}_{4} \rightarrow 3 \mathrm{CH}_{3} \mathrm{HC}=\mathrm{N}-\mathrm{OH}+3 \mathrm{H}_{2} \mathrm{O}+\mathrm{H}_{3} \mathrm{PO}_{4} \\
\mathrm{H}_{3} \mathrm{PO}_{4}+\text { base } \rightarrow \text { phosphate (discoloring) }
\end{gathered}
$$
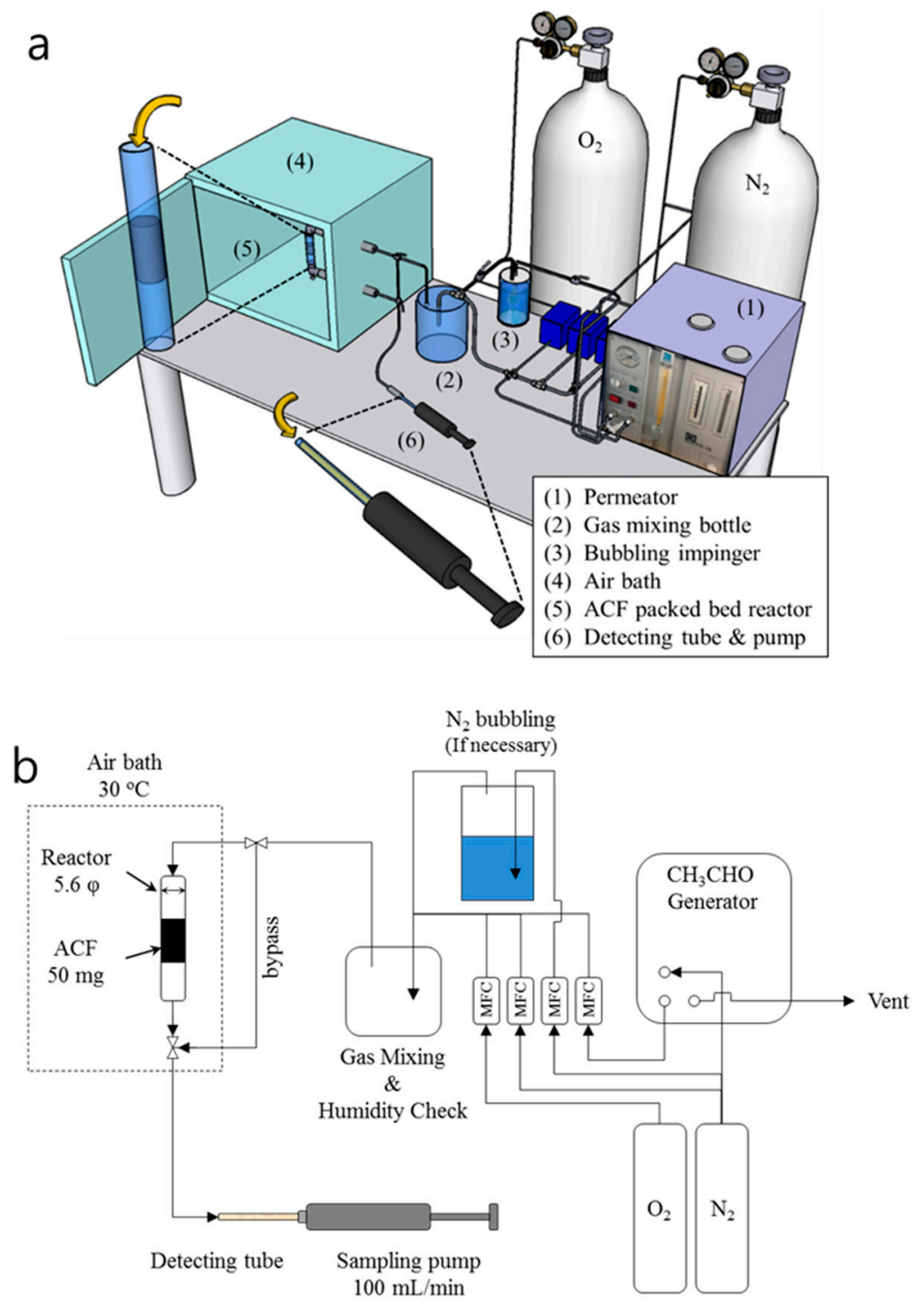

Figure 1. (a) Schematic illustration of $\mathrm{CH}_{3} \mathrm{CHO}$ adsorption and detection system and (b) diagram of the whole system.

\section{3. $2 D-G C$ and TOF-MS}

GC $\times$ GC (2D GC) was coupled with TOF-MS to analyze the chemical compounds of feeds and products over the adsorbents at the given conditions (Table 1). The 2D GC TOF-MS experimental setup consisted of 7890B GC and 7200B TOF-MS equipment, manufactured by Agilent Technologies. In the 2D GC system, two different columns were used in the gas chromatography. A non-polar column was used for the first column and a polar column was used for the second column, which were eluted in 
order of their boiling point and polarity, respectively. In the 2D-GC TOF-MS spectrum, the horizontal axis shows the boiling point and the vertical axis shows the polarity. In the first column, a capillary tube of $30 \mathrm{~m}$ in length and $0.32 \mathrm{~mm}$ in inner diameter (I.D.) is used, and the temperature is ramped by $5{ }^{\circ} \mathrm{C} / \mathrm{min}$. The sample separated from the first column is introduced into the second column after cooling and leaving left in a modulator.The second column opens the GC with the same modulation time employed for short columns (length: $2 \mathrm{~m}$, I.D.: $0.18 \mathrm{~mm}$ ). Since both columns are heated in the same oven, they are almost constant when the sample reaches the second column. The separated compounds are ionized, and these ions are accelerated by a constant voltage.

Table 1. GC × GC TOF-MS measurement conditions.

\begin{tabular}{|c|c|c|}
\hline \multirow{8}{*}{ GC $\times$ GC System } & 1st column & BPX5 $(30 \mathrm{~m} \times 0.25 \mathrm{~mm}, 0.25 \mu \mathrm{m})$ \\
\hline & 2nd column & BPX50 $(2 \mathrm{~m} \times 0.10 \mathrm{~mm}, 0.1 \mu \mathrm{m})$ [cut in half] \\
\hline & Oven temperature & $90^{\circ} \mathrm{C}(1 \mathrm{~min}) \rightarrow\left[1{ }^{\circ} \mathrm{C} / \mathrm{min}\right] 230^{\circ} \mathrm{C}(0 \mathrm{~min})$ \\
\hline & Sample injection mode & Splitless \\
\hline & Sample injection temperature & $300{ }^{\circ} \mathrm{C}$ \\
\hline & Flow & $1.5 \mathrm{~mL} / \mathrm{min}$ [constant flow] \\
\hline & Modulation time & $9 \mathrm{~s}$ \\
\hline & Sample injection amount & $1.0 \mu \mathrm{L}$ \\
\hline \multirow{5}{*}{ TOF-MS system } & Ionization method & $\mathrm{EI}+$ \\
\hline & Ionization condition & $70 \mathrm{~V}, 300 \mu \mathrm{A}$ \\
\hline & Ion source temperature & $350{ }^{\circ} \mathrm{C}$ \\
\hline & Acquisition frequency & $50 \mathrm{~Hz}$ (0.02 sec/spectrum) \\
\hline & Mass range & $\mathrm{m} / \mathrm{z} 50-700$ \\
\hline
\end{tabular}

\section{Results and Discussion}

\subsection{Preliminary Test for Acetaldehyde Removal}

Before modifying the surface functional group with amine species over the adsorbents, preliminary tests are performed to compare the CACF with other commercials (Supplementary Data 1a). The breakthroughs for the conversion of acetaldehyde removal under the given conditions are in the following order: CACF $(\approx 0.4 \mathrm{~h})>\mathrm{K}-\mathrm{C}(\approx 0.15 \mathrm{~h})>\mathrm{MSP}-20(\approx 0.05 \mathrm{~h})>\mathrm{QW}(\approx 0 \mathrm{~h})$. In general, oxygen content is released as $\mathrm{CO}$ and $\mathrm{CO}_{2}$ from carboxyl groups conjugated with ketone or quinone, carboxyl groups in non-aromatic or aromatic compounds, carboxyl anhydrides, and lactone structures [29-31]. Thus, better performance of acetaldehyde over CACF might be attributed to the relative abundance of oxygen content on the surface.

To introduce the amine functional group, CACF calcification was performed at various temperatures. The CACF that was calcined at $1100^{\circ} \mathrm{C}(\mathrm{CACF}-\mathrm{H})$ showed an optimized acetaldehyde removal performance (Supplementary Data 1b). In previous reports [29-31], the temperature of calcination was adequate for the heat treatment of $\mathrm{ACF}$, being reasoned with the crystallinity and hydrophobicity. However, when CACF was calcined at $1400{ }^{\circ} \mathrm{C}$ its removal performance decreased, possibly due to the partial destruction of micropores and a rearrangement of the carbon structure into a graphitic structure.

\subsection{Acetaldehyde Removal Performance of Functionalized Amine}

In order to increase the acetaldehyde removal capability of CACF-H, an amine functional group using the primary chemical agent of aniline was introduced over $\mathrm{CACF}-\mathrm{H}$, where amine can also react strongly with aldehydes [32-35]. After introducing aniline on the CACF-H (A@CACF-H), all the parameters of pure character were decreased (Table 2) while the $\mathrm{N}$ content increased, indicating that the aniline was successfully loaded on the CACF-H surface. 
Table 2. Elemental composition and porosity characteristics of carbon materials.

\begin{tabular}{|c|c|c|c|c|c|c|c|}
\hline \multirow{2}{*}{ Sample } & \multicolumn{4}{|c|}{ Elemental Composition (\%) } & \multirow{2}{*}{$\begin{array}{c}\text { Specific Surface } \\
\text { Area }\left(\mathrm{m}^{2} \mathrm{~g}^{-1}\right)\end{array}$} & \multirow{2}{*}{$\begin{array}{c}\text { Average Pore } \\
\text { Width (nm) }\end{array}$} & \multirow{2}{*}{$\begin{array}{c}\text { Total Pore } \\
\text { Volume }\left(\mathrm{cm}^{3} \mathrm{~g}^{-1}\right)\end{array}$} \\
\hline & $\mathrm{C}$ & $\mathbf{H}$ & $\mathbf{N}$ & $\mathrm{O}_{(\text {diff.) }}$ & & & \\
\hline $\mathrm{CACF}$ & 86.6 & 0.9 & 0.4 & 12.1 & 1525 & 0.77 & 0.58 \\
\hline CACF-H ${ }^{*}$ & 89.6 & 0.5 & 0.7 & 9.2 & 1368 & 0.81 & 0.55 \\
\hline A@CACF-H & 87.7 & 1.6 & 3.8 & 6.9 & 445 & 1.24 & 0.26 \\
\hline
\end{tabular}

CACF-H* $\mathrm{H}^{*}$ denotes calcined at $1100{ }^{\circ} \mathrm{C}$ for $1 \mathrm{~h}$. $\left.\mathrm{O}_{(\text {diff.) }}\right)^{*}$ denotes differential amount.

The breakthrough curves for the acetaldehyde removal of A@CACF-H with different aniline contents are presented in Figure 2a. All the A@CACF-H samples showed greatly increased acetaldehyde removal capabilities with longer breakthrough times than pristine CACF-H under the given conditions. As expected, removal capability was enhanced by increasing the aniline amount from $1 \%$ to $2 \%$, where the $2 \%$ content A@CACF-H sample showed the highest amount of acetaldehyde removal among the tested samples. From the data for acetaldehyde removal, provided in Figure 2b, the removal capability of the $2 \%$ content A@CACF-H sample was almost 400 times larger than that of the pristine CACF-H, which reveals the effect of the $\mathrm{N}$-functional group on acetaldehyde removal.
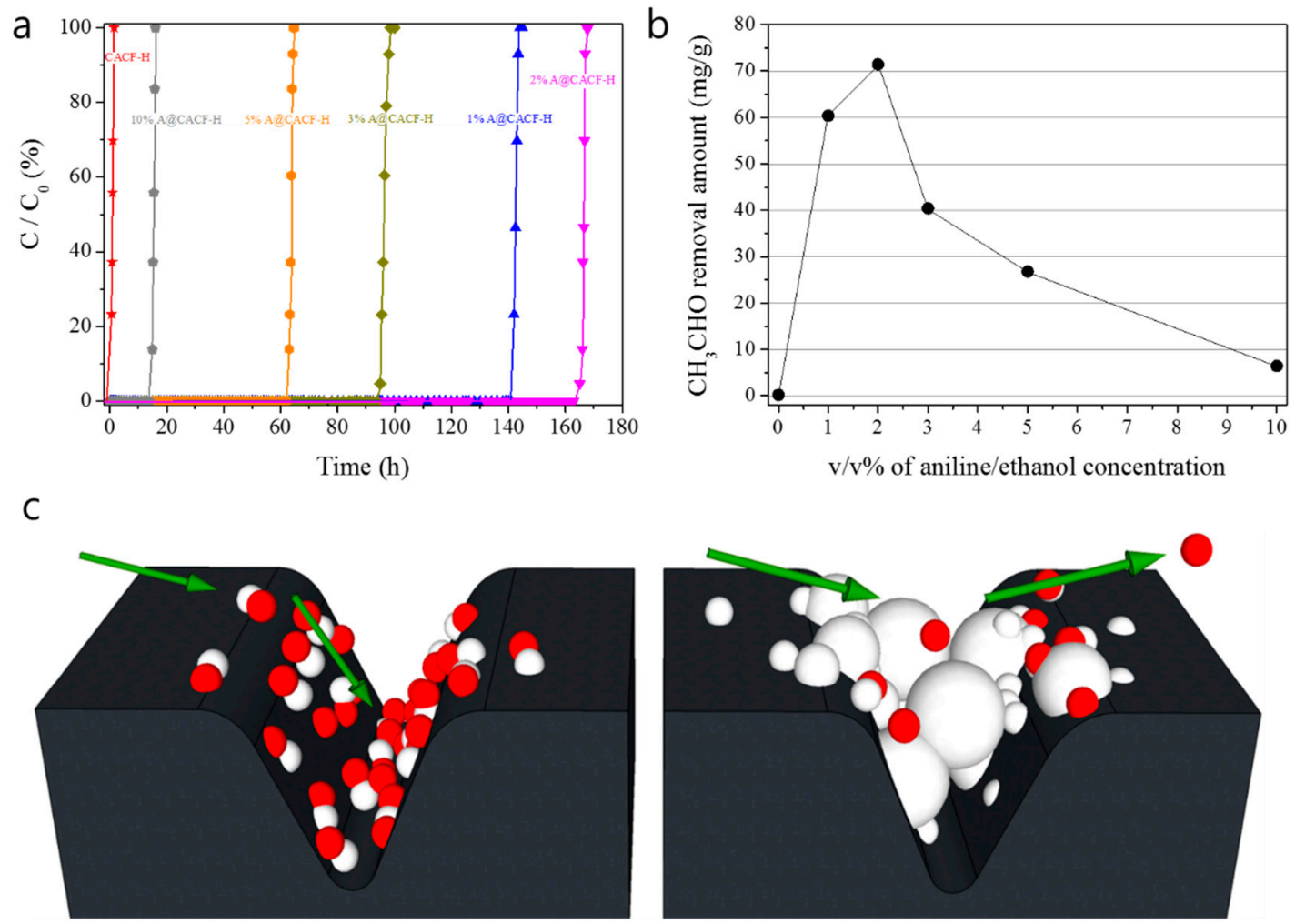

(a) Uniformly deposited aniline

(b) Excessively deposited aniline

White particles denote supported aniline and red particle denote the acetaldehyde respectively.

Figure 2. Comparison of $\mathrm{CH}_{3} \mathrm{CHO}$ adsorption: (a) performance and (b) calculated removal amounts of CACF-H and A@CACF-H with different aniline concentrations, as well as (c) the aniline and acetaldehyde behavior in the micropores of CACF-H when (a) uniformly deposited and (b) excessively deposited. 
It is of note that samples with an aniline content above $2 \%$ exhibited a drastically reduced acetaldehyde removal capability. Table 3 shows the amounts of aniline that are supported on the CACF-H samples by each aniline-ethanol solution in units of mmol. When the absolute amount of aniline present in a sample was more than $2 \%$, the acetaldehyde uptake amounts decreased from 3.30 to 0.14 mol. This is because excess supported aniline may block the entrance of the micropores, as shown in Figure 2c, which inhibits the physisorption of acetaldehyde and its oxidation reaction. With the optimized amount of aniline, the supporting effect of aniline on removal capability is further confirmed by preparing and evaluating other porous carbons such as QW, MSP-20, and K-C, using the same treatment (Figure 3). The acetaldehyde removal capabilities of aniline-treated MSP-20 and $\mathrm{K}-\mathrm{C}$ are, remarkably, increased by approximately 350 and 220 times, respectively. Although the $\mathrm{N}$-functionalized QW showed almost no improvement due to its very low surface area, we found that the amine functional group from aniline enhanced the acetaldehyde removal for all other porous carbons. However, the A@CACF-H was still the best absorbent for acetaldehyde removal, which was confirmed by the removal capability trends of the non-treated carbons.

Table 3. Elucidation of total removed amount and removal ratio of acetaldehyde by aniline supported CACF-H.

\begin{tabular}{ccccccc}
\hline & $\begin{array}{c}\text { Total } \\
\text { Removed } \\
\text { Amount } \\
\text { [mg/g] }\end{array}$ & $\begin{array}{c}\text { Breakthrough } \\
\text { Time [h] }\end{array}$ & $\begin{array}{c}\text { Supported } \\
\text { Aniline } \\
\text { Amount [\%] }\end{array}$ & $\begin{array}{c}\text { Supported } \\
\text { Aniline } \\
\text { Amount } \\
\text { [mmol] }\end{array}$ & $\begin{array}{c}\text { Total Removed } \\
\text { Amount of } \\
\text { Acetaldehyde } \\
\text { [mmol] }\end{array}$ & $\begin{array}{c}\text { Acetaldehyde } \\
\text { Uptake Amount } \\
\text { Ratio by 1 mol of } \\
\text { Aniline }\end{array}$ \\
\hline 1\% A@CACF-H & 60.5 & 142 & 4.3 & 0.023 & 0.076 & 3.30 \\
2\% A@CACF-H & 70.7 & 165 & 7.8 & 0.042 & 0.088 & 2.09 \\
3\% A@CACF-H & 40.9 & 95 & 8.7 & 0.047 & 0.051 & 0.033 \\
5\% A@CACF-H & 27.0 & 63 & 9.9 & 0.053 & 0.03 & 0.14 \\
$10 \%$ A@CACF-H & 6.5 & 15 & 10.7 & 0.057 & 0.08 \\
\hline
\end{tabular}

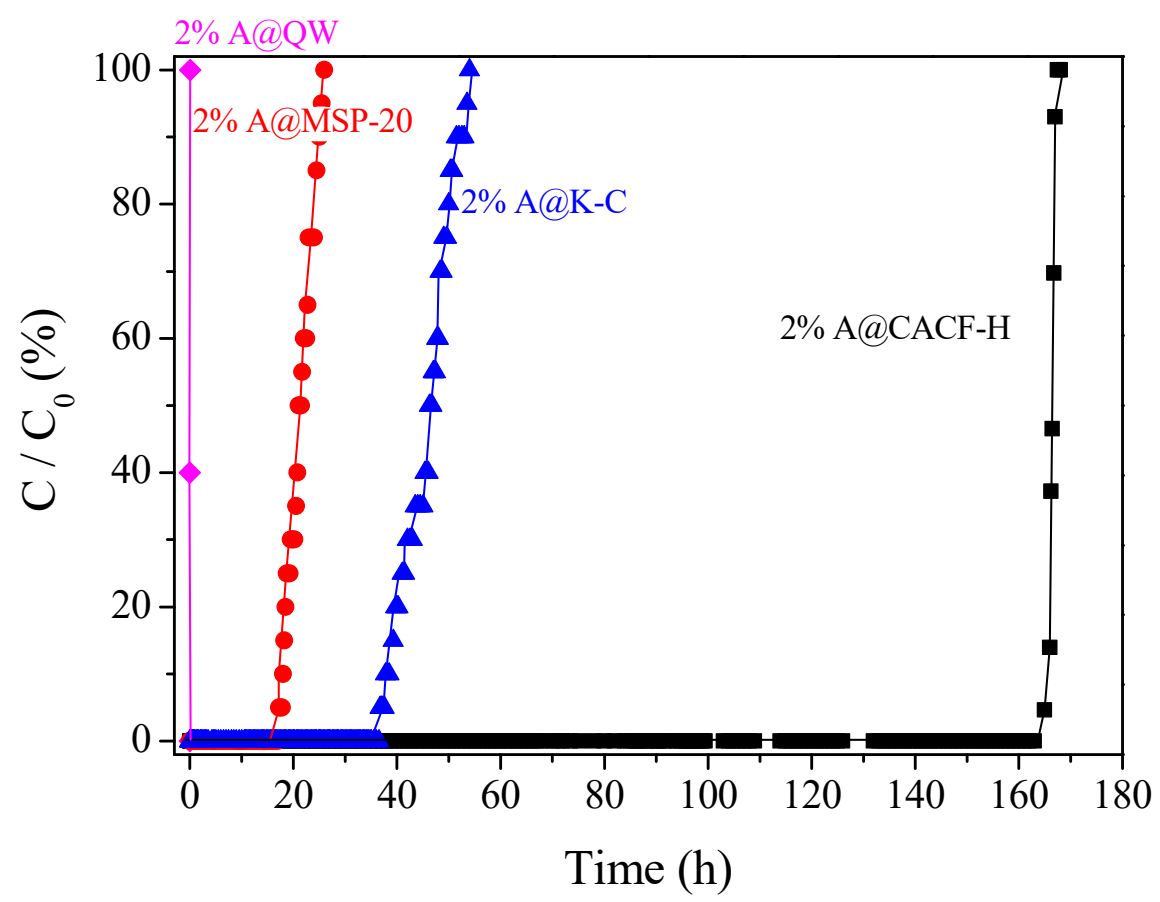

Figure 3. The comparison of $\mathrm{CH}_{3} \mathrm{CHO}$ adsorption performances of $2 \%$ aniline supported samples of CACF-H, MSP-20, K-C, and quartz wool (QW). 


\subsection{D GC TOF-MS Results}

The results of 2D GC TOF-MS analysis before and after adsorption of 2\% A@CAVF-H under a relative humidity $(\mathrm{RH})$ of $40 \%$ are shown in Figure 4 , with a summary of their molecular identifications provided in Tables 4 and 5. This detailed molecular information can be used to predict the reaction mechanisms that occur during the adsorption process. Based on the summarized molecular identifications, it may be speculated that the reaction between acetaldehyde and the amine functional group occurs via two reaction pathways.

First, acetic acid oxidized by the acetaldehyde may react with the amine functional group to form an amide species (7), (8), and (9) in Figure 4). In the case of aniline (Figure 4), a stronger aniline peak (No. 3) is observed before acetaldehyde removal compared to the other substances. This intensity decreased by more than 3 times, which was calculated by the GC-MS, showing aniline content reduction from $320 \mathrm{mg} / \mathrm{L}$ to $51 \mathrm{mg} / \mathrm{L}$, comparing before and after the acetaldehyde removal test. In contrast, various produced amide species, such as N-phenyl-formamide, N-phenyl-glyoxylamide, and $\mathrm{N}$-phenyl-acetamide, were detected after the acetaldehyde removal test.

Second, 2-methyl-quinoline can be produced though a reaction between amine and the aldol condensates of acetaldehyde. The reaction pathway for the formation of 2-methyl-quinoline may follow the Skraup-Doebner-Von Miller or Mannich reactions (Figure 5) [36,37]. In the case of a Skraup-Doebner-Von Miller reaction, an aldol condensation of acetaldehydes is catalyzed by the supported amine, which usually occurs in the micropores. The formation of 2-methyl-quinoline through the Skraup-Doebner-Von Miller reaction [36,37] is shown in Figure 5. In the case of the Mannich reaction, the acetaldehyde reacts with aniline to form an imine structure. Some of the acetaldehyde converts to a more stable state of vinyl alcohol $\left(\mathrm{CH}_{2}=\mathrm{CH}-\mathrm{OH}\right)$. The quinoline formation reaction then occurs. Others can be suggested in terms of the $\mathrm{N}$-species, both from the CACF-H itself and the column materials of the GC system. Therefore, the formation of amide species and 2-methyl-quinoline from acetaldehyde over the adsorbent can be described as the main behavior.

Table 4. Detected chemical species from $2 \%$ of A@CACF-H before De- $\mathrm{CH}_{3} \mathrm{CHO}$ test. Chemical species were extracted by the $\mathrm{CDCl}_{3}$.

\begin{tabular}{|c|c|c|c|c|c|c|}
\hline No. & Value & Name & Formula & $\begin{array}{l}\text { Match } \\
\text { Factor }\end{array}$ & CAS \# & $\begin{array}{l}\text { Molecular } \\
\text { Weight }\end{array}$ \\
\hline (1) & 276194 & 2-Chloronicotinoitrile & $\mathrm{C} 6 \mathrm{H} 3 \mathrm{ClN} 2$ & 529 & $6602-54-6$ & 138 \\
\hline (2) & 4607653 & Carbamoyl chloride, phenyl- & C7H6ClNO & 711 & $2040-76-8$ & 155 \\
\hline (3) & 45761364 & Aniline & C6H7N & 845 & $62-53-3$ & 93 \\
\hline (4) & 985755 & $\begin{array}{c}\text { Phenylalanine, } \\
\text { 4-amino-N-t-butyloxycarbonyl-, } \\
\text { t-butyl ester }\end{array}$ & $\mathrm{C} 18 \mathrm{H} 28 \mathrm{~N} 2 \mathrm{O} 4$ & 512 & $0-00-0$ & 336 \\
\hline (5) & 1872067 & $\begin{array}{c}\text { Methanamine, } \\
\text { N-(1-phenylethylidene)- }\end{array}$ & $\mathrm{C} 9 \mathrm{H} 11 \mathrm{~N}$ & 611 & $6907-71-7$ & 133 \\
\hline (6) & 868060 & o-Chloroaniline & $\mathrm{C} 6 \mathrm{H} 6 \mathrm{ClN}$ & 628 & $95-51-2$ & 127 \\
\hline (7) & 570027 & m-Chloroaniline & $\mathrm{C} 6 \mathrm{H} 6 \mathrm{ClN}$ & 617 & $108-42-9$ & 127 \\
\hline (8) & 2831315 & $\begin{array}{l}\text { Propanedinitrile, } \\
\text { (ethoxymethylene)- }\end{array}$ & $\mathrm{C} 6 \mathrm{H} 6 \mathrm{~N} 2 \mathrm{O}$ & 682 & $123-06-8$ & 122 \\
\hline (9) & 46303 & 1H-Pyrrole, 2-phenyl- & $\mathrm{C} 10 \mathrm{H} 9 \mathrm{~N}$ & 663 & $3042-22-6$ & 143 \\
\hline (11) & 1194857 & Quinoline, 2-methyl- & $\mathrm{C} 10 \mathrm{H} 9 \mathrm{~N}$ & 837 & $91-63-4$ & 143 \\
\hline (11) & 4887046 & $\begin{array}{c}\text { Pyridine, } \\
\text { 2-aminomethyl-6-methyl- }\end{array}$ & C7H10N2 & 790 & $6627-60-7$ & 122 \\
\hline 12 & 538737 & Bis(2-chloroethyl)ethylamine & $\mathrm{C} 6 \mathrm{H} 13 \mathrm{Cl} 2 \mathrm{~N}$ & 670 & $538-07-8$ & 169 \\
\hline 13 & 407290 & $\begin{array}{l}\text { Methanimidamide, } \\
\text { N,N'-diphenyl- }\end{array}$ & $\mathrm{C} 13 \mathrm{H} 12 \mathrm{~N} 2$ & 771 & $622-15-1$ & 196 \\
\hline (14) & 554214 & 9-Hexadecenoic acid & $\mathrm{C} 16 \mathrm{H} 30 \mathrm{O} 2$ & 752 & $2091-29-4$ & 254 \\
\hline
\end{tabular}


Table 5. Detected chemical species from 2\% A@CACF-H after De- $\mathrm{CH}_{3} \mathrm{CHO}$ test. Chemical species were extracted by the $\mathrm{CDCl}_{3}$.

\begin{tabular}{ccccccc}
\hline No. & Value & Name & Formula & $\begin{array}{c}\text { Match } \\
\text { Factor }\end{array}$ & CAS \# & $\begin{array}{c}\text { Molecular } \\
\text { Weight }\end{array}$ \\
\hline (1) & 14217646 & Aniline & C6H7N & 828 & $62-53-3$ & 93 \\
(2) & 5934255 & Amfetamine & C9H13N & 744 & $300-62-9$ & 135 \\
(3) & 7638604 & Benzaldehyde, 3-methyl- & C8H8O & 869 & $620-23-5$ & 120 \\
(4) & 5129038 & Cyclohexasiloxane, dodecamethyl- & C12H36O6Si6 & 851 & $540-97-6$ & 444 \\
(5) & 54896184 & Quinoline, 2-methyl- & C10H9N & 873 & $91-63-4$ & 143 \\
(6) & 5541745 & Isoquinoline & C9H7N & 903 & $119-65-3$ & 129 \\
(7) & 23662350 & Formamide, N-phenyl- & C7H7NO & 896 & $103-70-8$ & 121 \\
(8) & 1943815 & Glyoxylamide, N-phenyl- & C9H9NO2 & 842 & $32331-52-5$ & 163 \\
(9) & 3061044 & Acetamide, N-phenyl- & C8H9NO & 889 & $103-84-4$ & 135 \\
11) & 29294004 & Cycloheptasiloxane, tetradecamethyl- & C14H42O7Si7 & 881 & $107-50-6$ & 518 \\
11 & 988329 & Cyclooctasiloxane, hexadecamethyl- & C16H48O8Si8 & 867 & $556-68-3$ & 592 \\
12 & 599084 & 4-Pyrrolylbenzaldehyde & C11H9NO & 795 & $23351-05-5$ & 171 \\
13 & 8573484 & Azobenzene & C12H10N2 & 887 & $103-33-3$ & 182 \\
14 & 2134871 & Ethyl 2-anilinomethylenepropionate & C12H15NO2 & 724 & $0-00-0$ & 205 \\
15 & 8318584 & Carbazole, 3,4-dimethyl- & C14H13N & 874 & $18992-72-8$ & 195 \\
(16) & 14102031 & 1H-Pyrazole-4-carboxaldehyde, & C16H12N2O & 771 & $21487-45-6$ & 248 \\
(1) & 4912176 & 1,3-diphenyl- & C17H18N2 & 684 & $72151-03-2$ & 250 \\
18 & 2942095 & 2-Phenylamino-4,6-diphenylpyrimidine & C22H17N3 & 701 & $300358-58-1$ & 323 \\
\hline \multicolumn{7}{c}{}
\end{tabular}

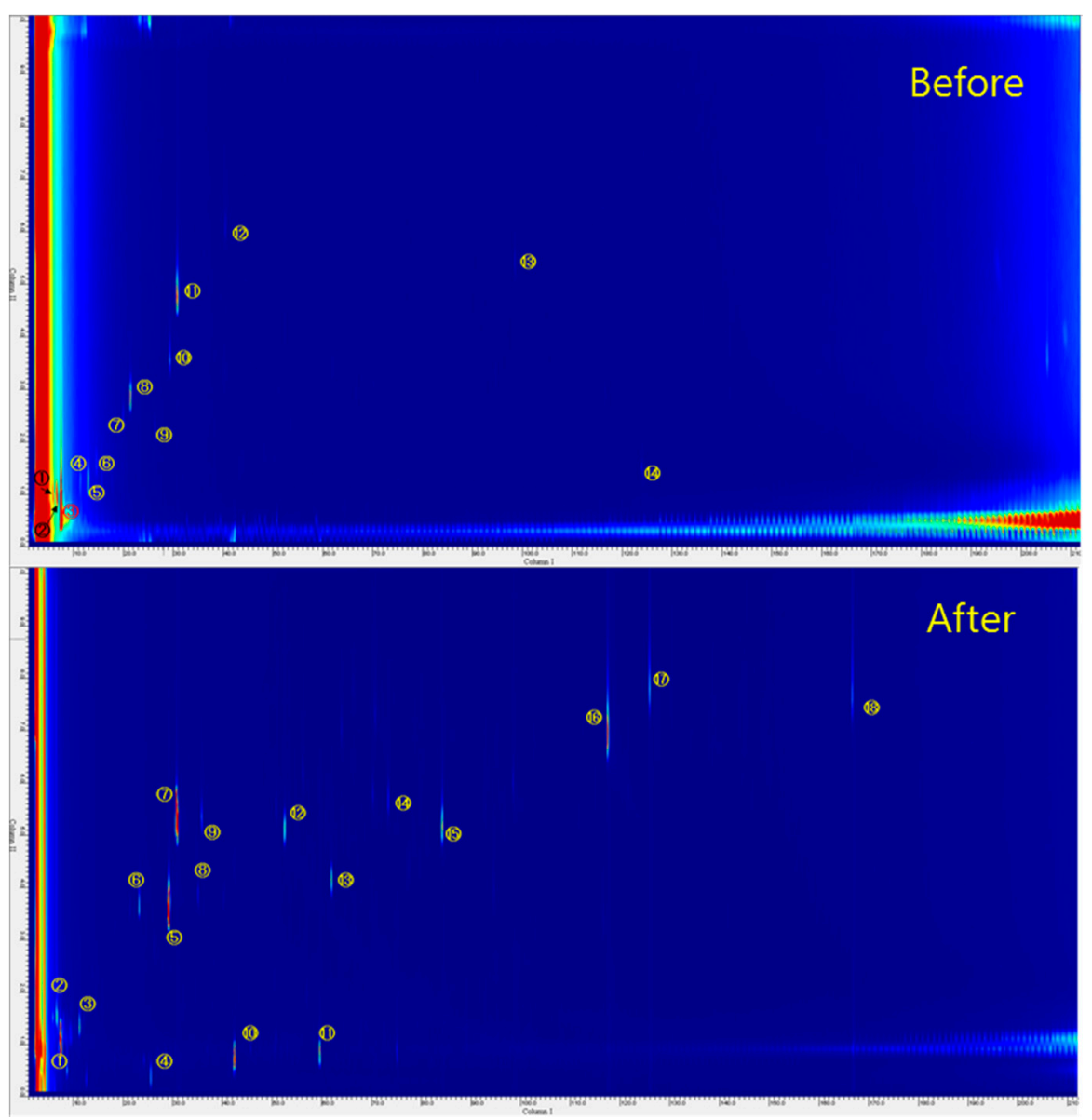

Figure 4. GC $\times$ GC TOF-MS spectra of $2 \%$ of A@CACF-H before and after De- $\mathrm{CH}_{3} \mathrm{CHO}$ test (extraction solvent: $\left.\mathrm{CDCl}_{3}\right)$. 


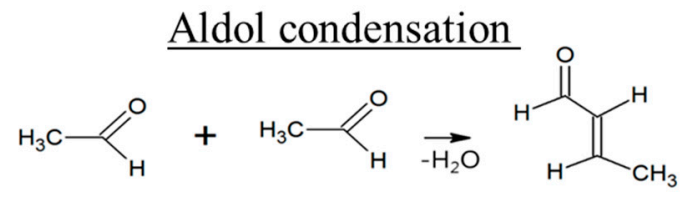

\section{$\underline{\text { Skraup-Doebner-Von Miller Reaction }}$}

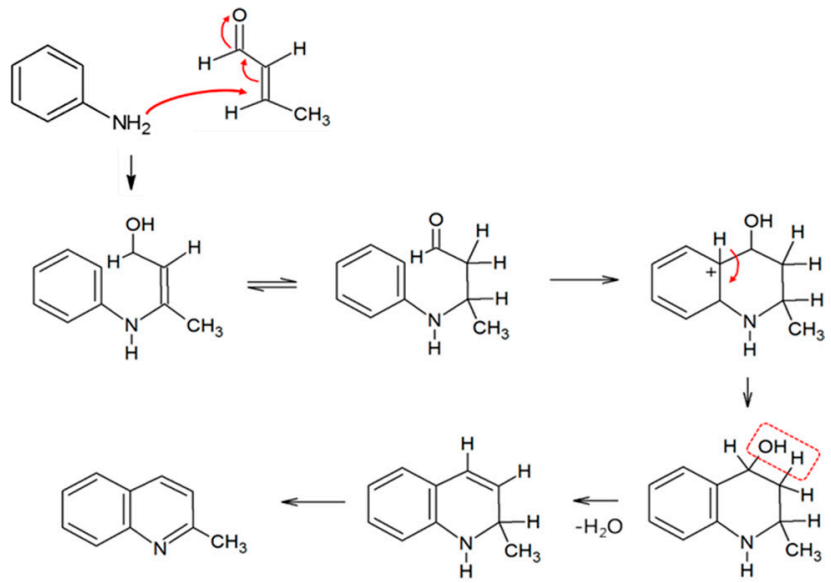

\section{Mannich Reaction}
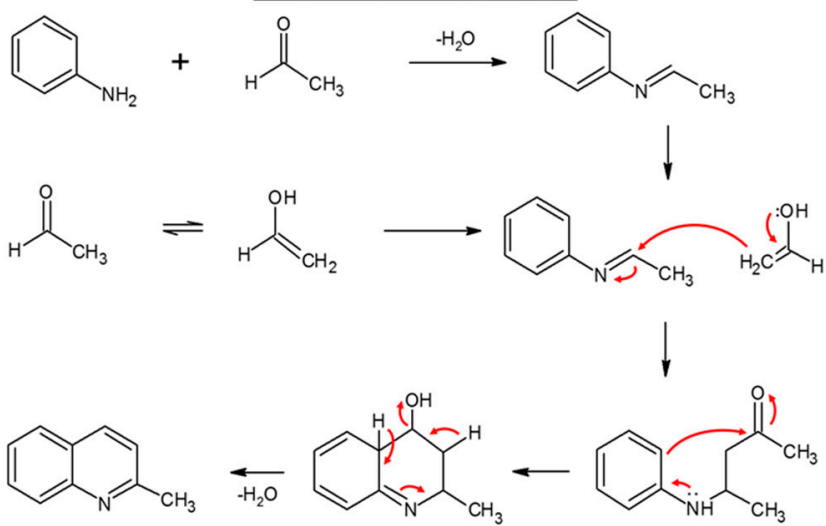

Figure 5. Aldol condensation of acetaldehyde under basic conditions and formation of 2-methyl-quinoline followed by the Skraup-Doebner-Von Miller and Mannich reactions.

\subsection{Acetaldehyde Removal Mechanisms}

Based on the 2D-GC TOF-MS analyses, we may propose the following formation reaction mechanism for acetanilide (9) in Figure 4):

(1) $\mathrm{CH}_{3} \mathrm{CHO}_{(\mathrm{g})} \rightarrow \mathrm{CH}_{3} \mathrm{CHO}_{(\mathrm{AD})}$ [Adsorption]

(2) $\mathrm{CH}_{3} \mathrm{CHO}_{(\mathrm{AD})}+\frac{1}{2} \mathrm{O}_{2} \rightarrow \mathrm{CH}_{3} \mathrm{COOH}$ [Oxidation]

(3) $2 \mathrm{CH}_{3} \mathrm{COOH} \rightarrow\left(\mathrm{CH}_{3} \mathrm{CO}\right)_{2} \mathrm{O}+\mathrm{H}_{2} \mathrm{O}$ [Dehydration]

(4) $\left(\mathrm{CH}_{3} \mathrm{CO}\right)_{2} \mathrm{O}+\mathrm{C}_{6} \mathrm{H}_{5} \mathrm{NH}_{2} \rightarrow \mathrm{C}_{6} \mathrm{H}_{5} \mathrm{NCH}_{3} \mathrm{CO}-\mathrm{CH}_{3} \mathrm{COOH}$

First, the acetaldehyde can be physically adsorbed onto the active sites in the A@CACF-H. The active sites with oxygen ("O') and nitrogen ("N") on the A@CACF-H are allowed to make a hydrogen bonding with hydrogen in the water vapor and with the acetaldehyde molecules. In general, the water vapor in air may occupy the pores of the carbon material, which tend to hinder gas removal. In this study, the concentration of acetaldehyde is $2 \mathrm{ppm}$, and so the number of acetaldehyde molecules is significantly lower than that of the $\mathrm{H}_{2} \mathrm{O}$ molecules under a relative humidity of $40 \%$. The acetaldehyde and $\mathrm{H}_{2} \mathrm{O}$ molecules competitively adsorb onto the micropores of the carbon material. As a result, the active sites in the micropores of the carbon material are blocked by $\mathrm{H}_{2} \mathrm{O}$ molecules. However, due 
to its hydrophilicity, acetaldehyde tends to be caught in moisture (the thin water film on the surface) that penetrates into the micropores. Then, it can be oxidized into acetic acid on the active sites in the micropores. This acetic acid from the micropores may then spill over the surface, and react with the functionalized amine to form amide structures such as N-phenyl-acetamide or acetanilide [38].

To verify the amide structure formation through the acetaldehyde-aniline reaction, the experimental conditions were changed from (a) $\mathrm{O}_{2} 21 \% \mathrm{v} / \mathrm{v}$ under $\mathrm{RH}$ of $40 \%$, to (b) $\mathrm{O}_{2} 21 \% \mathrm{v} / \mathrm{v}$ under $\mathrm{RH}$ of $0 \%$, and (c) $\mathrm{O}_{2} 0 \% \mathrm{v} / \mathrm{v}$ under $\mathrm{RH}$ of $0 \%$, as shown in Figure 6. Under the conditions of (c), the acetaldehyde-aniline reaction may not occur. A certain amount of the acetaldehyde was removed even without the $\mathrm{O}_{2}$, indicating that a small amount of acetaldehyde can be captured by the functionalized amine. However, compared to the conditions with $\mathrm{O}_{2}$ and/or $\mathrm{H}_{2} \mathrm{O}$, it is not affordable to effectively remove acetaldehyde without an oxidation reaction.

Hence, the dominant behavior of acetaldehyde adsorption over the adsorbent can be confirmed by the formation of amide species such as acetanilide. Generally, it has been speculated and reported, so far, that the chemical reaction between amine and aldehyde formed mainly imine species $[33,36,37,39]$. In this study, we attempted to confirm the detailed and objective mechanism of acetaldehyde adsorption, using the high resolution 2D TOF-MS over the surface functionalized (amine) microporous media. As a result, amide species can also be considered as the main intermediates during the adsorption of acetaldehyde over the media.

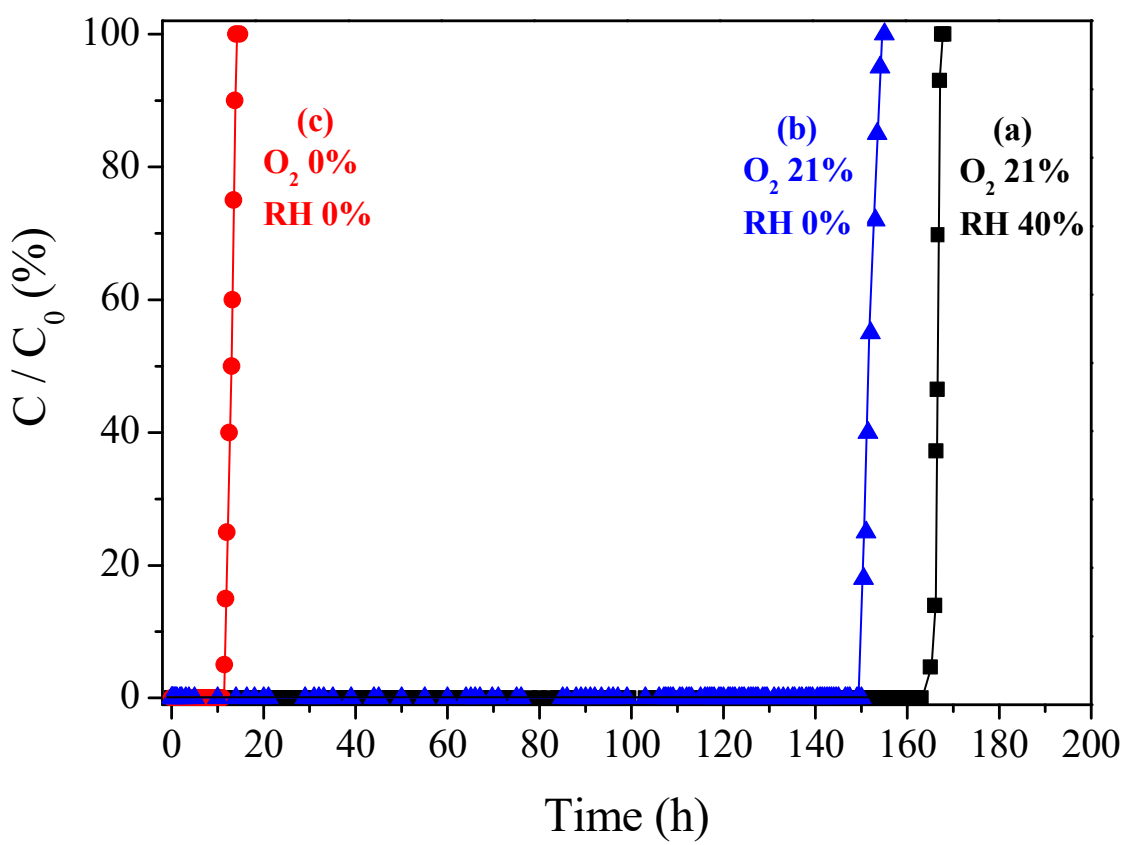

Figure 6. Comparison of $\mathrm{CH}_{3} \mathrm{CHO}$ removal performance over $2 \%$ A@CACF-H at (a) $\mathrm{O}_{2} 21 \%$ under $\mathrm{RH}$ $0 \%$ and (b) $\mathrm{O}_{2} 0 \%$ under $\mathrm{RH} 0 \%$.

\section{Conclusions}

A cellulose-based ACF is proposed as the candidate for acetaldehyde removal under $40 \%$ humidity conditions. To improve acetaldehyde removal efficiency, the CACF was heat-treated at an optimal temperature of $1100{ }^{\circ} \mathrm{C}$. Moreover, functionalization of the amine with aniline was used to drastically enhance the removal performance of the heat-treated adsorbent. Our results suggest that the main reaction pathway involves the formation of acetanilide (amide species) from the intermediates of acetic acid and aldol condensates, and also 2-methyl-quionoline through Skraup-Doebner-Von Miller and Mannich based reactions. These findings help to elucidate the processes underpinning acetaldehyde removal from ACFs, and provide a novel type of CACF together with a potential removal approach which may be adopted and applied in various settings in which polluting VOCs appear. 
Supplementary Materials: The following are available online at http://www.mdpi.com/2076-3417/10/1/25/s1, Comparison of $\mathrm{CH}_{3} \mathrm{CHO}$ adsorption performances over a. different commercial adsorbent materials such as MSP-20, K-C, and quartz wool (QW), as well as b. the calcined CACFs at various temperatures.

Author Contributions: Investigation, Conceptualization, Methodology, Data Curation, Project Administration, Supervision, Writing (original draft, review \& editing) and Funding acquisition from S.-H.Y. and J.-I.P.; Experiment, Data processing, Software and Formal Analysis from D.-Y.R., K.N., T.S., U.M., I.M., J.M. and Y.J. All authors have read and agreed to the published version of the manuscript.

Funding: This work was carried out within the framework of National Research Foundation of Korea (NRF-2019R1F1A1060122).

Conflicts of Interest: The authors declare no conflict of interest and there is no copyright issue in all of figures.

\section{References}

1. Zhang, J.; Smith, K.R. Emissions of carbonyl compounds from various cookstoves in China. Environ. Sci. Technol. 1999, 33, 2311-2320. [CrossRef]

2. Seeman, J.I.; Dixon, M.; Haussmann, H.J. Acetaldehyde in mainstream tobacco smoke: Formation and occurrence in smoke and bioavailability in the smoker. Chem. Res. Toxicol. 2002, 15, 1331-1350. [CrossRef] [PubMed]

3. Hodan, W.M.; Barnard, W.R. Evaluating the contribution of PM2. 5 precursor gases and re-entrained road emissions to mobile source PM2. 5 particulate matter emissions. In MACTEC Federal Programs; Research Triangle Park: Raleigh, NC, USA, 2004.

4. Cogliano, V.J.; Grosse, Y.; Baan, R.A.; Straif, K.; Secretan, M.B.; Ghissassi, F.E. Working Group for Volume 88. Meeting report: Summary of IARC monographs on formaldehyde, 2-butoxyethanol, and 1-tert-butoxy-2-propanol. Environ. Health Perspect. 2005, 113, 1205-1208. [CrossRef] [PubMed]

5. Hauptmann, M.; Lubin, J.H.; Stewart, P.A.; Hayes, R.B.; Blair, A. Mortality from solid cancers among workers in formaldehyde industries. Am. J. Epidemiol. 2004, 159, 1117-1130. [CrossRef]

6. Hodgson, A.T.; Faulkner, D.; Sullivan, D.P.; Dibartolomeo, D.L.; Russell, M.L.; Fisk, W.J. Effect of outside air ventilation rate on volatile organic compound concentrations in a call center. Atmos. Environ. 2003, 37, 5517-5527. [CrossRef]

7. Lahousse, C.; Bernier, A.; Grange, P.; Delmon, B.; Papaefthimiou, P.; Ioannides, T.; Verykios, X. Evaluation of $\gamma-\mathrm{MnO}_{2}$ as a VOC removal catalyst: Comparison with a noble metal catalyst. J. Catal. 1998, 178, $214-225$. [CrossRef]

8. Finnegan, M.J.; Pickering, C.A.; Burge, P.S. The sick building syndrome: Prevalence studies. Br. Med. J. Clin. Res. Ed. 1984, 289, 1573-1575. [CrossRef]

9. Nikawa, T.; Naya, S.I.; Tada, H. Rapid removal and decomposition of gaseous acetaldehyde by the thermo-and photo-catalysis of gold nanoparticle-loaded anatase titanium (IV) oxide. J. Colloid Interface Sci. 2015, 456, 161-165. [CrossRef]

10. Main, D.M.; Hogan, T.J. Health effects of low-level exposure to formaldehyde. J. Occup. Environ. Med. Off. Publ. Ind. Med. Assoc. 1983, 25, 896-900. [CrossRef]

11. World Health Organization. Environmental Health Criteria; World Health Organization: Geneva, Switzerland, 1995; p. 167.

12. Busca, G.; Berardinelli, S.; Resini, C.; Arrighi, L. Technologies for the removal of phenol from fluid streams: A short review of recent developments. J. Hazard. Mater. 2008, 160, 265-288. [CrossRef]

13. Gnesdilov, N.N.; Dobrego, K.V.; Kozlov, I.M. Parametric study of recuperative VOC oxidation reactor with porous media. Int. J. Heat Mass Transf. 2007, 50, 2787-2794. [CrossRef]

14. Kennes, C.; Thalasso, F. Waste gas biotreatment technology. J. Chem. Technol. Biotechnol. 1998, 72, 303-319. [CrossRef]

15. Delhoménie, M.C.; Heitz, M. Biofiltration of air: A review. Crit. Rev. Biotechnol. 2005, 25, 53-72. [CrossRef] [PubMed]

16. Gabelman, A.; Hwang, S.T. Hollow fiber membrane contactors. J. Membr. Sci. 1999, 159, 61-106. [CrossRef]

17. Ruhl, M.J. Recover VOCs via adsorption on activated carbon. Chem. Eng. Prog. 1993, 89, 37-41.

18. Bradley, R.H. Recent developments in the physical adsorption of toxic organic vapours by activated carbons. Adsorpt. Sci. Technol. 2011, 29, 1-28. [CrossRef] 
19. Das, D.; Gaur, V.; Verma, N. Removal of volatile organic compound by activated carbon fiber. Carbon 2004, 42, 2949-2962. [CrossRef]

20. Singh, K.P.; Mohan, D.; Tandon, G.S.; Gupta, G.S.D. Vapor-phase adsorption of hexane and benzene on activated carbon fabric cloth: Equilibria and rate studies. Ind. Eng. Chem. Res. 2002, 41, 2480-2486. [CrossRef]

21. Baur, G.B.; Yuranov, I.; Renken, A.; Kiwi-Minsker, L. Activated carbon fibers for efficient VOC removal from diluted streams: The role of surface morphology. Adsorption 2015, 21, 479-488. [CrossRef]

22. Lillo-Ródenas, M.A.; Cazorla-Amorós, D.; Linares-Solano, A. Behaviour of activated carbons with different pore size distributions and surface oxygen groups for benzene and toluene adsorption at low concentrations. Carbon 2005, 43, 1758-1767. [CrossRef]

23. Lillo-Ródenas, M.A.; Cazorla-Amorós, D.; Linares-Solano, A. Benzene and toluene adsorption at low concentration on activated carbon fibres. Adsorption 2011, 17, 473-481. [CrossRef]

24. Baur, G.B.; Yuranov, I.; Kiwi-Minsker, L. Activated carbon fibers modified by metal oxide as effective structured adsorbents for acetaldehyde. Catal. Today 2015, 249, 252-258. [CrossRef]

25. Balanay, J.A.G.; Crawford, S.A.; Lungu, C.T. Comparison of toluene adsorption among granular activated carbon and different types of activated carbon fibers (ACFs). Appl. Occup. Environ. Hyg. 2011, 8, 573-579. [CrossRef] [PubMed]

26. Yi, F.Y.; Lin, X.D.; Chen, S.X.; Wei, X.Q. Adsorption of VOC on modified activated carbon fiber. J. Porous Mater. 2009, 16, 521-526. [CrossRef]

27. Dumitrică, T. Intrinsic Twist in I $\beta$ Cellulose Microfibrils by Tight-Binding Objective Boundary Calculations. Carbohydr. Polym. 2019, 115624. [CrossRef]

28. Miyawaki, J.; Lee, G.H.; Yeh, J.; Shiratori, N.; Shimohara, T.; Mochida, I.; Yoon, S.H. Development of carbon-supported hybrid catalyst for clean removal of formaldehyde indoors. Catal. Today 2012, 185, 278-283. [CrossRef]

29. Shin, S.; Jang, J.; Yoon, S.H.; Mochida, I. A study on the effect of heat treatment on functional groups of pitch based activated carbon fiber using FTIR. Carbon 1997, 35, 1739-1743. [CrossRef]

30. Szymański, G.S.; Karpiński, Z.; Biniak, S.; Światkowski, A. The effect of the gradual thermal decomposition of surface oxygen species on the chemical and catalytic properties of oxidized activated carbon. Carbon 2002, 40, 2627-2639. [CrossRef]

31. Figueiredo, J.L.; Pereira, M.F.R.; Freitas, M.M.A.; Órfão, J.J.M. Modification of the surface chemistry of activated carbons. Carbon 1999, 37, 1379-1389. [CrossRef]

32. Rivelino, R. Lewis Acid-Base Interactions in Weakly Bound Formaldehyde Complexes with CO2, HCN, and FCN: Considerations on the Cooperative H-Bonding Effects. J. Phys. Chem. A 2008, 112, 161-165. [CrossRef]

33. Sprung, M.A.A. Summary of the Reactions of Aldehydes with Amines. Chem. Rev. 1940, 26, $297-338$. [CrossRef]

34. Song, Y.; Qiao, W.; Yoon, S.H.; Mochida, I.; Guo, Q.; Liu, L. Removal of formaldehyde at low concentration using various activated carbon fibers. J. Appl. Polym. Sci. 2007, 106, 2151-2157. [CrossRef]

35. Lee, K.J.; Miyawaki, J.; Shiratori, N.; Yoon, S.H.; Jang, J. Toward an effective adsorbent for polar pollutants: Formaldehyde adsorption by activated carbon. J. Hazard. Mater. 2013, 260, 82-88. [CrossRef] [PubMed]

36. Bergstrom, F.W. Heterocyclic Nitrogen Compounds. Part II A. Hexacyclic Compounds: Pyridine, Quinoline, and Isoquinoline. Chem. Rev. 1944, 35, 77-277. [CrossRef]

37. Denmark, S.E.; Venkatraman, S. On the mechanism of the Skraup-Doebner- Von Miller quinoline synthesis. J. Org. Chem. 2006, 71, 1668-1676. [CrossRef]

38. Kralj, A.K. Checking the kinetics of acetic acid production by measuring the conductivity. J. Ind. Eng. Chem. 2007, 13, 631-636.

39. Baur, G.B.; Spring, J.; Kiwi-Minsker, L. Amine functionalized activated carbon fibers as effective structured adsorbents for formaldehyde removal. Adsorption 2018, 24, 725-732. [CrossRef]

(C) 2019 by the authors. Licensee MDPI, Basel, Switzerland. This article is an open access article distributed under the terms and conditions of the Creative Commons Attribution (CC BY) license (http://creativecommons.org/licenses/by/4.0/). 